\title{
Differences in Perceived Health Status Outcomes among Heterosexual, Homosexual (Gay or Lesbian) and Bisexual Korean adolescents*
}

\section{Diferencias en el estatus de salud percibido entre adolescentes coreanos heterosexuales, homosexuales (gays o lesbianas) y bisexuales}

Received: May 26 $6^{\text {th }}, 2014$ | Revised: August $15^{\text {th }}, 2014 \mid$ Accepted: October $10^{\text {th }}, 2014$

\author{
DONG-IL SEO ** \\ Dongguk University, Gyeong-Ju, Republic of Korea \\ DONG JUN SUNG ${ }^{* * *}$ \\ Konkuk University, Chungju-si, Republic of Korea \\ WIYYOUNG SO ${ }^{* * * *}$ \\ Korea National University of Transportation, \\ Chungju-si, Republic of Korea
}

doi:10.11144/Javeriana.upsy14-1.dphs

To cite this article: Seo, D.I., Sung, D. J., \& So, W. J. (2015). Differences in perceived health status outcomes among heterosexual, homosexual (gay or lesbian) and bisexual Korean adolescents. Universitas Psychologica, 14(1), 339-344. http://dx.doi. org/10.11144/Javeriana.upsy14-1.dphs

Original research article. This study was supported by the Dongguk University Research Fund of 2012, Gyeongju, Korea. Authors declare that there is no conflict of interest.

** Assistant Professor, Department of Social Athletics, Dongguk University, Gyeong-Ju, Republic of Korea.

*** Assistant Professor, Division of Sport Science, College of Science and Technology, Konkuk University.

${ }^{* * * *}$ Assistant Professor, Sports and Health Care Major, College of Humanities and Art. E-mail: sls98@kku. ac.kr
A B S T R A C T

The purpose of this study was to examine differences in perceived health status outcomes among heterosexual, homosexual (gay or lesbian), and bisexual Korean adolescents. Originally, in 2012, over 70,000 adolescents aged 12-18 years participated in the Eighth Korea Youth Risk Behavior Web-based Survey (KYRBWS-VIII). However, only 11,829 adolescents provided information on their sexual experiences and behaviors, such as kissing, fondling, and sexual orientations, i.e., homosexual (gay or lesbian), bisexual, or heterosexual. Therefore, data from only 11,829 adolescents surveyed were analyzed using a one-way analysis of variance, with a Scheffe post-hoc test, to determine the differences in perceived health status outcomes among Korean adolescents of the different sexual orientation groups. Boys across all 3 groups showed significant differences in general health status $(p=0.004)$, happiness $(p=$ 0.045), and getting sufficient sleep ( $p=0.004)$.

Further, Scheffe post-hoc comparisons of group mean scores revealed that homosexual (gay) boys had poorer overall health $(p=0.004)$ and bisexual boys had less sufficient sleep ( $p=0.017)$; however, there were no significant differences in happiness between homosexual (gay) $(p=0.651)$ and bisexual boys $(p=0.064)$ as compared to heterosexual boys. Moreover, there were no significant differences in general body shape $(p=0.320)$ and oral health $(p$ $=0.549)$ among the 3 groups we studied. Girls differed significantly in general body shape $(p=0.026)$ across all 3 groups in the results of the one-way ANOVA we performed. However, according to Scheffe post-hoc analyses, no significant differences existed in general body shape among girls in both the homosexual (lesbian) and bisexual groups ( $p=0.112$ and 0.204 , respectively). Additionally, there were no significant differences in general health status ( $p$ $=0.113)$, happiness $(p=0.602)$, oral health $(p=0.290)$, and getting sufficient sleep $(p=0.481)$ among adolescent girls in all 3 groups. From these results, we concluded that, in general, homosexual (gay or lesbian) and bisexual Korean teens do not differ significantly from heterosexual Korean teens in perceived health status outcomes.

Keywords

bisexual; gay; heterosexual; homosexual; lesbian; perceived health 


\section{RESUMEN}

El propósito de este estudio fue examinar las diferencias en los resultados del estado de salud percibido entre adolescentes coreanos heterosexuales, homosexuales (gays o lesbianas) y bisexuales. Originalmente, en 2012, más de 70.000 adolescentes de 12 a 18 años participaron en la Octava Encuesta Coreana para la Juventud sobre comportamientos riesgosos (KYRBWS-VIII). Sin embargo, sólo 11.829 adolescentes proporcionaron información sobre sus experiencias sexuales y comportamientos, como los besos, las caricias, y orientaciones sexuales, es decir, homosexual (gay o lesbiana), bisexual o heterosexual. Por lo tanto, los datos de sólo 11.829 adolescentes encuestados fueron analizados mediante un análisis de varianza, con una prueba post-hoc de Scheffe, para determinar las diferencias en los resultados del estado de salud percibido entre los adolescentes coreanos de los diferentes grupos de orientación sexual. Jóvenes en todos los 3 grupos mostraron diferencias significativas en el estado de salud general $(\mathrm{p}=$ $0,004)$, la felicidad $(\mathrm{p}=0,045)$, y dormir lo suficiente $(\mathrm{p}=$ 0,004). Además, las comparaciones de grupo post-hoc de Scheffe muestran las puntuaciones significativas que revelan que los homosexuales (gay) chicos tenían peor salud general $(p=0,004)$ y los chicos bisexuales presentaban una deficiencia en el sueño ( $p=0,017)$; sin embargo, no hubo diferencias significativas en la felicidad entre homosexual (Gay) ( $p=$ $0,651)$ y chicos bisexuales $(p=0,064)$ en comparación con los niños heterosexuales. Por otra parte, no hubo diferencias significativas en la forma general del cuerpo $(\mathrm{p}=0,320)$ y la salud oral $(p=0,549)$ entre los 3 grupos estudiados. Las niñas difieren significativamente en la forma del cuerpo general $(\mathrm{p}=$ $0,026)$ en todos los 3 grupos en los resultados de la ANOVA de una vía. Sin embargo, de acuerdo con el análisis post-hoc de Scheffe, no existen diferencias significativas en forma general del cuerpo de las niñas, tanto en el homosexual (lesbiana) y bisexuales ( $p=0,112$ y 0,204, respectivamente). Además, no hubo diferencias significativas en el estado de salud general $(p=0,113)$, la felicidad $(p=0,602)$, la salud oral $(p=0,290)$, y dormir lo suficiente $(p=0,481)$ entre las adolescentes en los 3 grupos. A partir de estos resultados, se concluye que, en general, los adolescentes homosexuales (gays o lesbianas) y bisexuales de Corea no difieren significativamente de los adolescentes coreanos heterosexuales en los resultados del estado de salud percibido.

Palabras clave

Bisexual; Gay; heterosexual; homosexual; lesbiana; salud percibida

\section{Introduction}

In the 2012 Gallup Special Report, the Williams Institute reported that $3.4 \%$ of adults in the United States identified as lesbian, gay, bisexual, or transgender LGBT (Gates, 2012). National LGBT statistics have been reported in many recent studies; for example, the percentage of gay/lesbian and bisexual adults in the United Kingdom was estimated at 1.1\% (545,000 adults) and $0.4 \%$ (220,000 adults), respectively, in 2012 (UK Office for National Statistics, 2012).

Furthermore, previous research has shown that the LGBT population worldwide has grown in recent years (Gates, 2012; UK Office for National Statistics, 2012; Layte, et., 2006; Melbye \& Biggar, 1992; Smith, Rissel, Richters, Grulich, \& de Visser, 2003) and that health problems and disparities exist in the population (Dilley, Simmons, Boysun, Pizacani, \& Stark, 2010; Duncan, Hatzenbuehler, \& Johnson, 2013; Johns, Pingel, Youatt, Soler, McClelland, \& Bauermeister, 2013; Lee, AgnewBrune, Clapp, \& Blosnich, 2013). For this reason, the social health issues of the LGBT population have received much attention from the global public as well as their respective societies.A recent study on Korean youth by Yoon and So (2013) found differences in lifestyle-related factors, including physical activity, between LGB and heterosexual adolescents, and concluded that LGB adolescents adopted less healthy lifestyle behaviors in comparison to heterosexual adolescents. Although this study examined the lifestyle patterns of LGB adolescents in Korea, their health status outcomes (e.g., physical and mental health) remain largely unknown.

Taking the next step in this relatively new line of research following Yoon and So's (2013) groundbreaking exploration, our study sought to determine whether perceived health status outcomes differed among heterosexual, homosexual (lesbian, gay), and bisexual Korean adolescents. We believe that the findings of this study will provide a deeper understanding of the characteristics of LGB adolescents in Korea.

\section{Methods}

\section{Participants}

The Eighth Korea Youth Risk Behavior Web-based Survey (KYRBWS-VIII), a countrywide survey conducted in 2012, employed a complex sample design through which students aged $12-18$ years in as many 
as 400 middle schools and 400 high schools were surveyed to assess the health status of adolescents in Korea. The sample design incorporated clustering, stratification, and multistage sampling, which meant that the survey's sampling frame covered all of South Korea. In addition, the validity and reliability of the survey has been ascertained in previous studies (Bae, Joung, Kim, Kwon, Kim, \& Park, 2010a; 2010b).

Of a total of 76,980 students sampled, 74,186 participated in the KYRBWS-VIII. However, only 11,829 adolescents provided information pertaining to their sexual experiences and behaviors, such as kissing and fondling, as well as their sexual orientations, i.e., homosexual (gay or lesbian), bisexual, or heterosexual. Students were assigned unique ID-numbers by their classroom teachers, with which they could then access the survey's web page. Students were asked if they were willing to participate, and those who chose to enroll anonymously completed the questionnaire at school. Because the survey did not ask for personally identifying information (e.g., home addresses, social security and telephone numbers, names of students or schools, etc.), ethical approval was not required.

\section{Perceived health status outcomes}

Perceived health status outcomes were determined through five survey questions/items on which parti- cipants could rate themselves, on a scale of 5 possible answers. The five questions and their corresponding responses were: (Q1) "Which of these do you think best describes your general health status?" (1) very healthy, (2) quite healthy, (3) normal, (4) quite unhealthy, and (5) very unhealthy; (Q2) "Which of these do you think best describes your general body shape?" (1) very thin, (2) quite thin, (3) normal, (4) quite fat, and (5) very fat; (Q3) "How happy do you feel right now?" (1) very happy, (2) quite happy, (3) normal, (4) quite unhappy, and (5) very unhappy; (Q4) "What do you think of your oral health, including your teeth and gums?" (1) very good, (2) quite good, (3) normal, (4) quite bad, and (5) very bad; and (Q5) "Do you think you get enough sleep?" (1) more than enough, (2) enough, (3) not sure, (4) not enough, and (5) absolutely not enough.

\section{Participants defined as homosexual (lesbian and gay), bisexual, and heterosexual}

Male and female participants were defined as being homosexual (gay or lesbian), bisexual, or heterosexual according to their responses to the question, "Select each of these that you have experienced?" on the KYRBWS-VIII: (1) none of these, (2) kissing and fondling someone of the opposite sex, (3) sexual intercourse with someone of the opposite sex, (4) kissing and fondling someone of the same sex, (5) sexual intercourse with someone of the same sex, (6)

\section{TABLE 1}

Participant Characteristics

\begin{tabular}{lccc}
\hline Variables & Heterosexual & Homosexual(gay or lesbian) & Bisexual \\
\hline Boys & $(\mathrm{N}=6,501)$ & $(\mathrm{N}=323)$ & $(\mathrm{N}=243)$ \\
Age $($ years $)$ & $15.89 \pm 1.51$ & $15.26 \pm 1.73$ & $15.48 \pm 1.68$ \\
Height $(\mathrm{cm})$ & $172.75 \pm 6.69$ & $170.36 \pm 7.63$ & $172.22 \pm 7.54$ \\
Weight $(\mathrm{kg})$ & $62.74 \pm 10.62$ & $60.44 \pm 11.01$ & $61.60 \pm 11.58$ \\
Body mass index $\left(\mathrm{kg} / \mathrm{m}^{2}\right)$ & $20.95 \pm 2.92$ & $20.74 \pm 3.03$ & $20.67 \pm 3.03$ \\
Girls & $(\mathrm{N}=4,441)$ & $(\mathrm{N}=208)$ & $(\mathrm{N}=113)$ \\
Age (years) & $15.92 \pm 1.52$ & $15.12 \pm 1.95$ & $15.81 \pm 1.75$ \\
Height $(\mathrm{cm})$ & $160.53 \pm 5.13$ & $161.35 \pm 6.61$ & $164.05 \pm 7.1$ \\
Weight $(\mathrm{kg})$ & $52.76 \pm 7.19$ & $52.97 \pm 8.79$ & $55.03 \pm 8.72$ \\
Body mass index $\left(\mathrm{kg} / \mathrm{m}^{2}\right)$ & $20.45 \pm 2.46$ & $20.29 \pm 2.79$ & $20.41 \pm 2.72$ \\
\hline
\end{tabular}

Data are expressed as mean \pm standard deviation Source: own work 
sexual violence from others, and (7) sexual violence to others. On the basis of their responses, we divided participants into 3 groups: (a) the homosexual group, or those who selected (4) and/or (5); (b) the bisexual group, or those who selected both (4) and/ or (5) and (2) and/or (3); and (c) the heterosexual group, or those who chose (2) and/or (3).

Since the subjects who answered "none of these" (1), "sexual violence from others" (6), and/or "sexual violence to others" (7) were not able to identify whether they were homosexual (gay or lesbian), bisexual or heterosexual, they were excluded from the study. In the end, data analyses were performed on 6,501 boys and 4,441 girls in the heterosexual group, 323 boys and 208 girls in the homosexual (gay or lesbian) group, and 243 boys and 113 girls in the bisexual group. In other words, only 11,829 adolescents checked responses (2) - (5) on the survey; the characteristics of these participants are shown in Table 1.

\section{Statistical analysis}

All of the results from this study are shown as the mean \pm the standard deviation. One-way analysis of variance (ANOVA) was used to verify inter-group differences in perceived health status outcomes among the 3 groups (heterosexual, homosexual, and bisexual). Scheffe post-hoc testing was conducted to confirm specifically which groups showed differences in perceived outcomes when a difference between groups occurred. The statistical significance was set at $p<0.05$ and analyses were performed using SPSS Version 18.0.

\section{Results}

Differences in perceived health status outcomes among Korean adolescents in the heterosexual, homosexual (gay or lesbian), and bisexual groups are shown in Table 2. Boys showed significant di-

TABle 2.

Differences among homosexual (gay or lesbian), bisexual, and heterosexual Korean adolescents in perceived health status outcomes

\begin{tabular}{|c|c|c|c|c|c|}
\hline & Heterosexual & $\begin{array}{l}\text { Homosexual } \\
\text { (gay or lesbian) }\end{array}$ & Bisexual & $\begin{array}{l}\text { Overall } \\
\mathrm{F}\end{array}$ & $\begin{array}{c}\text { Overall } \\
p\end{array}$ \\
\hline Boys & $(\mathrm{N}=6,501)$ & $(\mathrm{N}=323)$ & $(\mathrm{N}=243)$ & & \\
\hline $\begin{array}{l}\text { Which of these do you think best describes } \\
\text { your general health status? }\end{array}$ & $2.04 \pm 0.86$ & $2.21 \pm 0.97 \# \#$ & $2.05 \pm 0.97 \mathrm{~N} / \mathrm{S}$ & 5.647 & $0.004^{* *}$ \\
\hline $\begin{array}{l}\text { Which of these do you think best describes } \\
\text { your general body shape? }\end{array}$ & $2.82 \pm 0.97$ & $2.88 \pm 1.02 \mathrm{~N} / \mathrm{S}$ & $2.88 \pm 1.0 \mathrm{~N} / \mathrm{S}$ & 1.138 & $0.32 \mathrm{~N} / \mathrm{S}$ \\
\hline How happy do you feel right now? & $2.4 \pm 1.0$ & $2.46 \pm 1.08 \mathrm{~N} / \mathrm{S}$ & $2.56 \pm 1.19 \mathrm{~N} / \mathrm{S}$ & 3.092 & $0.045^{*}$ \\
\hline $\begin{array}{l}\text { What do you think of your oral health, } \\
\text { including your teeth and gums? }\end{array}$ & $2.8 \pm 0.95$ & $2.8 \pm 1.05 \mathrm{~N} / \mathrm{S}$ & $2.87 \pm 1.11 \mathrm{~N} / \mathrm{S}$ & 0.60 & $0.549 \mathrm{~N} / \mathrm{S}$ \\
\hline Do you think you sleep enough? & $3.30 \pm 1.12$ & $3.2 \pm 1.24 \mathrm{~N} / \mathrm{S}$ & $3.51 \pm 1.26 \#$ & 5.481 & $0.004 * *$ \\
\hline Girls & $(\mathrm{N}=4,441)$ & $(\mathrm{N}=208)$ & $(\mathrm{N}=113)$ & & \\
\hline $\begin{array}{l}\text { Which of these do you think best describes } \\
\text { your general health status? }\end{array}$ & $2.48 \pm 0.88$ & $2.43 \pm 0.94 \mathrm{~N} / \mathrm{S}$ & $2.32 \pm 1.12 \mathrm{~N} / \mathrm{S}$ & 2.181 & $0.113 \mathrm{~N} / \mathrm{S}$ \\
\hline $\begin{array}{l}\text { Which of these do you think best describes } \\
\text { your general body shape? }\end{array}$ & $3.27 \pm 0.9$ & $3.13 \pm 1.01 \mathrm{~N} / \mathrm{S}$ & $3.12 \pm 1.12 \mathrm{~N} / \mathrm{S}$ & 3.658 & $0.026^{*}$ \\
\hline How happy do you feel right now? & $2.7 \pm 1.0$ & $2.64 \pm 1.09 \mathrm{~N} / \mathrm{S}$ & $2.65 \pm 1.22 \mathrm{~N} / \mathrm{S}$ & 0.507 & $0.602 \mathrm{~N} / \mathrm{S}$ \\
\hline $\begin{array}{l}\text { What do you think of your oral health, } \\
\text { including your teeth and gums? }\end{array}$ & $3.03 \pm 0.92$ & $2.93 \pm 1.04 \mathrm{~N} / \mathrm{S}$ & $3.02 \pm 1.20 \mathrm{~N} / \mathrm{S}$ & 1.238 & $0.29 \mathrm{~N} / \mathrm{S}$ \\
\hline Do you think you sleep enough? & $3.53 \pm 1.05$ & $3.51 \pm 1.14 \mathrm{~N} / \mathrm{S}$ & $3.42 \pm 1.19 \mathrm{~N} / \mathrm{S}$ & 0.732 & $0.481 \mathrm{~N} / \mathrm{S}$ \\
\hline
\end{tabular}

${ }^{*} p<0.05 ;{ }^{*} p<0.01$ by one-way analysis of variance

$\mathrm{N} / \mathrm{S}$, not significant, \#p $<0.05 \#$ \# $<0.01$, when compared to heterosexual group (Scheffe post-hoc test)

Source: own work 
fferences in general health status $(p=0.004)$, happiness $(p=0.045)$, and getting enough sleep $(p=$ 0.004 ) across all 3 groups, according to the one-way ANOVA. The Scheffe posthoc test further revealed that homosexual (gay) boys scored higher (or wor$s e$, in this case) in terms of general health status ( $p$ $=0.004$ ), whereas bisexual boys scored higher (or worse, in this case) regarding sufficient sleep $(p=$ 0.017). However, homosexual (gay) and bisexual boys were not significantly happier or unhappier than their heterosexual male peers $(p=0.651$ and 0.064 , respectively). Moreover, there were no significant differences in general body shape $(p=0.32)$ and oral health $(p=0.549)$ among the 3 groups.

Girls showed significant differences in general body shape ( $p=0.026)$ across the 3 groups (heterosexual, homosexual or lesbian, and bisexual) according to the one-way ANOVA, however Scheffe posthoc comparisons of group means showed no significant differences in general body shape among both homosexual (lesbian) and bisexual girls ( $p=$ 0.112 and 0.204 , respectively). Moreover, we found no significant differences among all 3 groups in general health status $(p=0.113)$, happiness $(p=$ 0.602), oral health $(p=0.29)$, and getting sufficient sleep $(p=0.481)$.

\section{Discussion}

The purpose of this study was to examine whether perceived health status outcomes differed among heterosexual, homosexual (lesbian, gay), and bisexual Korean adolescents. Although studies focusing on health problems among LGBT individuals are few worldwide, several have shown poor physical functioning and mental health in this population (Case et al., 2004; Cochran \& Mays, 2007;. Sandfort, Bakker, Schellevis, \& Vanwesenbeeck, 2006). Moreover, Dilley et al. (2010) reported that LGBT individuals were at greater risk of suffering numerous negative health consequences due to their risky sexual behaviors, and had access to fewer protective health care services compared with their heterosexual counterparts.

In a recent study on Korean youth, Yoon and So (2013) reported that LGB adolescents had the worst smoking, drinking (alcohol) and physical activity practices/habits both among boys and girls. Their study regarding Korean LGB adolescents confirms previous findings on health disparities that exist in the LGB population and the less healthy lifestyles they may lead, as reflected in their higher smoking rates and greater alcohol consumption.

However, our results differed slightly from Yoon and So's (2013) in that although LGB boys had the worst overall health and least sufficient sleep (only two factors), homosexual (gay or lesbian) and bisexual adolescents did not differ significantly in perceived health status outcomes, in general, from heterosexual boys and girls.

A probable explanation might be that the period of adolescence is one of rapid physical growth and hormonal development, during which adolescents may be at their highest levels of physical and mental health in comparison to other stages in their lifetime, even though previous studies have reported more negative lifestyle patterns among LGB adolescents than their heterosexual peers. In other words, in the case of adolescents, there are no significant differences in perceived health status outcomes between LGB and heterosexual individuals, despite the former's negative lifestyle-related factors. Because little is known about this issue still, further more well-designed studies need to be carried out to determine the causes and explanations for this observation.

Two main limitations became apparent while performing our research. Firstly, the results of this study cannot be generalized to the adult population in Korea as it is well known that sexual orientation in childhood and adolescence varies largely from that which might be continued into adulthood, even though the trend of sexuality in adolescence may affect its development across the lifespan. Secondly, as data on only 11,829 participants of the KYRBWS-VIII were analyzed in our study, it is impossible to generalize its findings to all Korean adolescents. However, we believe that this study will be a trigger or catalyst for other studies exploring the social-health issues of the LGB population in Korea. 


\section{Conclusion}

We concluded that, in general, homosexual (gay or lesbian) and bisexual adolescents do not show different perceived health status outcomes from their heterosexual peers.

\section{References}

Bae, J., Joung, H., Kim, J. Y., Kwon, K. N., Kim, Y., \& Park, S. W. (2010a). Validity of self-reported height, weight, and body mass index of the Korea Youth Risk Behavior Web-based Survey questionnaire. J Prev Med Public Health, 43(5), 396-402.

Bae, J., Joung, H., Kim, J. Y., Kwon, K. N., Kim, Y. T., \& Park, S. W. (2010b). Test-retest reliability of a questionnaire for the Korea Youth Risk Behavior Web-based Survey. J Prev Med Public Health, 43 (5), 403-410.

Case, P., Austin, S. B., Hunter, D. J., Manson, J. E., Malspeis, S., Willett, W. C., \& Spiegelman, D. (2004). Sexual orientation, health risk factors, and physical functioning in the Nurses' Health Study II. J Womens Health (Larchmt), 13 (9), 1033-1047.

Cochran, S. D., Mays, V. M. (2007). Physical health complaints among lesbians, gay men, and bisexual and homosexually experienced heterosexual individuals: results from the California Quality of Life Survey. Am J Public Health, 97(11), 2048-2055.

Dilley, J. A., Simmons, K. W., Boysun, M. J., Pizacani, B. A., \& Stark, M.J. (2010). Demonstrating the importance and feasibility of including sexual orientation in public health surveys: health disparities in the Pacific Northwest. Am J Public Health, 100(3), 460-467.

Duncan, D. T., Hatzenbuehler, M. L., \& Johnson, R. M. (2013). Neighborhood-level LGBT hate crimes and current illicit drug use among sexual minority youth. Drug Alcohol Depend, pii: S0376-8716(13)00468-7. doi: 10.1016/j.drugalcdep.2013.11.001.

Gates, G. J. (2012). Special Report: 3.4\% of U.S. Adults Identify as LGBT. Newport, Frank (October 18, 2012).
Gallup. Retrieved from http://www.gallup.com/ poll/158066/special-report-adults-identify-lgbt. aspx.

Johns, M. M., Pingel, E.S., Youatt, E. J., Soler, J. H., McClelland, S.I., \& Bauermeister, J. A. (2013). LGBT community, social network characteristics, and smoking behaviors in young sexual minority women. Am J Community Psychol, 52 (1-2), 141-154.

Layte, D. R., McGee, H., Quail, A., Rundle, K., Cousins, G., Donnelly, C ... Conroy R. (2006). The Irish Study of Sexual Health and Relationships Main Report The Crisis Pregnancy Agency and the Department of Health and Children. Retrieved from http://epubs. rcsi.ie/cgi/viewcontent.cgi?article $=1037 \&$ contex $\mathrm{t}=$ psycholrep.

Lee, J. G., Agnew-Brune, C. B., Clapp, J. A., \& Blosnich, J. R. (2013). Out smoking on the big screen: tobacco use in LGBT movies, 2000-2011. Tob Control, doi: 10.1136/tobaccocontrol-2013-051288, (Epub ahead of print).

Melbye, M., \& Biggar, R. J. (1992). Interactions between persons at risk for AIDS and the general population in Denmark. Am J Epidemiol, 135(6), 593-602.

Sandfort, T. G., Bakker, F., Schellevis, F. G., \& Vanwesenbeeck, I. (2006). Sexual orientation and mental and physical health status: findings from a Dutch population survey. Am J Public Health, 96(6), 1119-1125.

Smith, A. M., Rissel, C. E., Richters, J., Grulich, A. E., $\&$ de Visser, R. O. (2003). Sex in Australia: sexual identity, sexual attraction and sexual experience among a representative sample of adults. Aust N Z J Public Health, 27(2), 138-145.

UK Office for National Statistics (2012). Integrated Household Survey April 2011 to March 2012: Experimental Statistics. UK Office for National Statistics. Retrieved from http://www.ons.gov.uk/ons/ dcp171778_280451.pdf.

Yoon, J. H., \& So, W. Y. (2013). Differences in Lifestyles Including Physical Activity According to Sexual Orientation among Korean Adolescents. Iranian J Publ Health, 42(12), 1347-1353. 